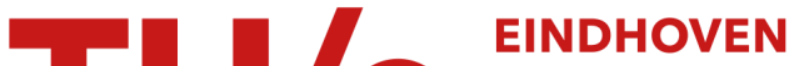

\section{Biosynthesis of poly-(R)-3-hydroxyalkanoate: an emulsion polymerization}

Citation for published version (APA):

Koning, de, G. J. M., \& Maxwell, I. A. (1993). Biosynthesis of poly-(R)-3-hydroxyalkanoate: an emulsion polymerization. Journal of Environmental Polymer Degradation, 3(1), 223-226.

https://doi.org/10.1007/BF02068676

DOI:

10.1007/BF02068676

Document status and date:

Published: 01/01/1993

\section{Document Version:}

Publisher's PDF, also known as Version of Record (includes final page, issue and volume numbers)

\section{Please check the document version of this publication:}

- A submitted manuscript is the version of the article upon submission and before peer-review. There can be important differences between the submitted version and the official published version of record. People interested in the research are advised to contact the author for the final version of the publication, or visit the $\mathrm{DOI}$ to the publisher's website.

- The final author version and the galley proof are versions of the publication after peer review.

- The final published version features the final layout of the paper including the volume, issue and page numbers.

Link to publication

\section{General rights}

Copyright and moral rights for the publications made accessible in the public portal are retained by the authors and/or other copyright owners and it is a condition of accessing publications that users recognise and abide by the legal requirements associated with these rights.

- Users may download and print one copy of any publication from the public portal for the purpose of private study or research.

- You may not further distribute the material or use it for any profit-making activity or commercial gain

- You may freely distribute the URL identifying the publication in the public portal.

If the publication is distributed under the terms of Article 25fa of the Dutch Copyright Act, indicated by the "Taverne" license above, please follow below link for the End User Agreement:

www.tue.nl/taverne

Take down policy

If you believe that this document breaches copyright please contact us at:

openaccess@tue.nl

providing details and we will investigate your claim. 


\title{
Biosynthesis of Poly-(R)-3-hydroxyalkanoate: An Emulsion Polymerization
}

\author{
G. J. M. de Koning ${ }^{1}$ and Ian A. Maxwell ${ }^{1,2}$
}

Poly-(R)-3-hydroxyalkanoates (PHAs) are bacterial storage polyesters, which are accumulated by a wide variety of microorganisms as a reserve of carbon and energy. Currently, these biopolymers are receiving much attention because of their potential application as biodegradable and biocompatible plastics. The polymer appears as submicron intracellular granules. The biosynthesis of these granules has been studied extensively but many observations remain inexplicable. This paper draws an analogy between the process of emulsion polymerization and that of granule formation. This analogy may explain many of the unknown features of granule formation and may also lead to useful applications of granules as latex products.

KEY WORDS: Emulsion polymerization; poly(hydroxyalkanoate); latex; biosynthesis.

\section{INTRODUCTION}

Poly- $(R)$-3-hydroxyalkanoates (PHAs) are linear biopolyesters, accumulated by a wide variety of bacteria as a reserve of carbon and energy $[1,2]$. Due to their natural origin PHAs are truly biodegradable [3]. Moreover, like many synthetics, PHAs are thermoplastic materials which can be easily melt-processed. Because of their potential application as biodegradable and biocompatible plastics [4], PHAs are currently receiving much attention.

Since Lemoigne [5] first isolated and characterized naturally abundant poly(hydroxybutyrate) in 1925, PHB has been extensively studied to elucidate its biosynthetic pathways. The polymer appears as distinct intracellular granules. In 1968 Ellar et al. [6] reported on the morphology of these granules and drew some analogies with the process of emulsion polymerization. They proposed that the polymerase enzymes are initially present as micelles which, upon subsequent polymerization, are transformed into crystalline granules. At present, how-

\footnotetext{
'Department of Polymer Chemistry and Technology, Eindhoven University of Technology, P.O. Box 513, $5600 \mathrm{MB}$ Eindhoven, The Netherlands.

${ }^{2}$ Current address: Sydney University Polymer Centre, University of Sydney, NSW 2006, Australia.
}

ever, it is well established [7] that nascent PHB is in the amorphous state. Ballard et al. [8] also noted in passing that PHB granules resemble polymer latex particles but did not expand this similarity to the process of their formation. The applicability of PHA as a latex product has been evaluated by Marchessault et al. [9, 10]. In this paper we develop a novel analogy between the biosynthesis of the granules, which is not presently well understood, and the well-studied process of emulsion polymerization, especially with regard to the physical chemistry of both processes.

\section{FEATURES OF PHA GRANULE FORMATION}

Ballard et al. [8] determined the number and size of granules in Alcaligenes eutrophus at intervals during PHB accumulation. He observed that the average number of granules per cell remained constant, so it appears that the number of granules per cell is fixed at the earliest stages of polymer accumulation. These granules increased uniformly for average diameters from 0.24 to $0.50 \mu \mathrm{m}$. At very high accumulation levels, however, granules often have very different diameters, ranging from 0.2 to $0.7 \mu \mathrm{m}$ in one cell [11].

Several ultrastructural studies $[11,12]$ demon- 
strated that the PHA granules are surrounded by a membrane coat approximately $2 \mathrm{~nm}$ thick. This membrane seems structurally less complex than the cell membrane and, since it is too thin to be a bilayer membrane, may consist of a lipid monolayer [12]. No extraneous particles and no internal structures have been seen within the granules [11] and analysis [13] revealed that the granule polymer is of remarkable purity. Granules isolated from $B$. megaterium appeared to be composed of PHB polymer, lipid, and protein, representing some 97.7, 0.5, and $1.8 \%$, respectively, of the granule weight. Phospholipids accounted for most of the lipid fraction and no neutral lipid was detected. The lipids and proteins are believed to constitute the membrane coat.

Presently, the generally supported granule model is that of a coil of amorphous polymer chains surrounded by a layer of phospholipids and proteins, which stabilize the interface between the hydrophobic contents of the granule and the aqueous environment. The granule-associated proteins, only some of which are known to be involved in the polymerization and depolymerization reactions [14-16], are located at this interface. Notably, both granule-associated and soluble polymerases, showing equal activity, were found to occur $[17,18]$. In the absence of polymer synthesis, the polymerase exists merely in the soluble form. Upon transition to conditions where PHB accumulation occurs, granule-associated PHB polymerase appears. Since the total amount of polymerase in the cells is constant, the rapid disappearance of soluble polymerase under these conditions is consistent with its association with PHB granules.

\section{ANALOGY OF PHA BIOSYNTHESIS WITH EMULSION POLYMERIZATION}

From the point of view of a polymer chemist, many of the experimentally observed features of granule formation can be explained by analogy with the process of emulsion polymerization. Of course, the analogous emulsion polymerization should involve a water-soluble monomer as is the case in PHA synthesis. In addition, it is known [19] that phospholipids are not able to form micelles under the accumulation conditions. In free radical emulsion polymerization the formation of latex particles in the absence of surfactant micelles occurs via homogeneous nucleation [20-22]. The basis of the homogeneous nucleation model is that water-soluble free radicals polymerize with water-solubilized monomer. When the oligomeric radicals so formed attain a certain degree of polymerization, they become insoluble and form a latex particle. Latex particle nucleation ceases when the latex particle surfaces present sufficient area to the aqueous phase radicals that these aqueous phase radicals adsorb onto existing latex particles rather than continuing to polymerize in the aqueous phase and becoming insoluble to form new particles.

Similar to free radical emulsion polymerization, high molecular weight polymer is being formed from the earliest stages of PHA accumulation [8, 23]. Molecular weights up to $1,200,000$ have even been reported [24]. The synthesis of these biopolyesters obviously does not follow the familiar polycondensation scheme but involves some chain reaction. Initially the polymerase enzymes are in the cytosol. Under conditions of nutrient starvation they are triggered and start to grow polymer chains by apposition of the monomer. The greater part of the monomer is linked to coenzyme A (CoA), in which form it is available to the polymerase system. The polymerase acquires the 3-hydroxyacylCoA from the cytoplasm and deploys it to elongate a polymer chain while CoASH is released. This yields surfactant-like molecules with the polymerase enzyme as the hydrophilic headgroup and the oligomeric chain as the hydrophobic tail. As the chains grow they become increasingly hydrophobic, and at a certain degree of polymerization they will collapse in order to minimize their surface and form latex particles (Fig. 1). Once sufficient surface has been created, any new nascent polymer chains will adsorb onto the surfaces of the existing latex particles, thus fixing the number of granules at an initial value. Since all polymerase enzymes are triggered at an early stage, the polymerase concentration in the cytoplasm rapidly decreases and all the enzyme becomes "granule associated." Some sporadic free enzyme which may be synthesized later or has desorbed from a surface will be caught by a granule surface as soon as it starts to grow a new polymer chain. Meanwhile the continuing production of polymer expands the granule, thus creating more surface area. Due to its hydrophobicity, this surface attracts surface-active species from the cytoplasm, e.g., proteins with an amphiphilic character and phospholipids which possess a structure similar to the surfactants used in emulsion polymerization. Moreover, desorption of polymerase leaves a carboxyl chain end [23] at the surface with concomitant stabilizing effects.

Since all granules are formed during the same period and grow at a rate according to their surface area, all granules grow at similar rates. This explains the monodispersity of the granule size during the early stages of polymerization. The ultimate polydispersity of the granule size may be attributed to limitations in the cellular volume. It was found [25] that the accumulated 




Fig. 1. Schematic presentation of the formation of a PHA granule.

PHA accounted for $93 \%$ of the volume increase of a cell, which implies that the granules possess a rapidly increasing packing density. This enhances coalescence of the granules, which indeed was observed by Tal and Okon [26].

\section{DISCUSSION}

Obviously, an analogy between PHA granule formation and emulsion polymerization can be drawn. There are, however, some major differences which might make the kinetics of the PHA biosynthesis much more complex than a typical emulsion polymerization. The monomer is continuously synthesized via a cascade of reactions, the rate of which are subject to variation during the PHA accumulation. Moreover, the intermediates not only are used in polymer synthesis, but also are involved in other processes of the cell metabolism. Finally, Kawaguchi and Doi $[23,27]$ suggested that the simultaneous synthesis and degradation of PHA can occur. Nevertheless, the extensive knowledge of the kinetics of emulsion polymerization reactions can be used to help elucidate the mechanisms of granule formation in bacteria. Toward these aims, studies are currently under way utilizing kinetic experiments typical for emulsion polymerization to study bacterial polymerization. Preliminary results indicate that the analogy indeed explains many of the unknown features of granule formation [28].

If PHA granules are synthesized according to an emulsion polymerization process, they may have applicability as a latex product $[9,10]$. Most importantly, compared to conventional emulsion polymer latices PHA latices have some very special features. First, all present industrial emulsion polymerization processes involve radical polymerizations implying that the poly- mers produced possess a carbon backbone. Therefore, PHA lattices are unique since they are polyesters. Second, PHAs are completely biodegradable, creating numerous possibilities for their use, especially in environmentally benign applications. Third, upon subjecting granules of PHB or its copolymers to specific treatments, the polymer readily crystallizes [29], resulting in a unique latex containing crystalline polymer. Many possible applications for these unique latices are foreseeable. We are presently studying these possibilities.

\section{REFERENCES}

1. E. A. Dawes and P. J. Senior, Adv. Microbiol. Physiol. 10, 135$266(1973)$.

2. A. J. Anderson and E. A. Dawes, Microbiol. Rev, 54, 450 472 (1990).

3. P. Barak, Y. Coquet, T. R. Halbach, and J. A. E. Molina, J. Environ. Qual. 20, 173-179 (1991).

4. P. A. Holmes, Phys. Technol. 16, 32-36 (1985).

5. M. Lemoigne, Ann. Inst. Pasteur Paris 39, 144-173 (1925).

6. D. Ellar, D. G. Lundgren, K. Okamura, and R. H. Marchessault, J. Mol. Biol. 35, 489-502 (1968).

7. G. N. Barnard and J. K. M. Sanders, J. Biol. Chem. 264, 32863291 (1988).

8. D. G. H. Ballard, P. A. Holmes, and P. J. Senior, Recent Adv. Mech. Synth. Aspects Pol. 215, 293-314 (1987).

9. R. H. Marchessault et al., PCT Int. Appl. WO 91, 13,207 (1990).

10. R. H. Marchessault et al., NATO ASI Ser. Ser. E 186, 97-112 (1990).

11. W. F. Dunlop and A. W. Robards, J. Bacteriol, 114, 1271-1280 (1973).

12. H. Preusting, J. Kingma, and B. Witholt, Enzym. Microbiol. Technol. 13, 770-780 (1991).

13. R. Griebel, Z. Smith, and J. M. Merrick, Biochemistry 7, 36763681 (1968).

14. J. M. Merrick and M. Doudoroff, Nature 189, 890-892 (1961).

15. M. Liebergesell, B. Schmidt, and A. Steinbüchel, FEMS Microbiol. Lett. 99, 227-232 (1992).

16. R. C. Fuller et al., FEMS Microbiol. Rev, 103, 279-288 (1992).

17. T. Fukui et al., Arch. Microbiol. 110, 149-156 (1976). 
18. G. W. Haywood, A. J. Anderson, and E. A. Dawes, FEMS Microbiol. Lett. 57, 1-6 (1989).

19. D. J. Mitchell and B. W. Ninham, J. Chem. Soc. Faraday Trans. 277,601 (1981).

20. R. M. Fitch and C. H. Tsai, in Polymer Colloids, R. M. Fitch, ed. (Plenum Press, New York, 1971).

21. J. Ugelstad and F. K. Hansen, Rubber Chem. Technol. 49, 536 (1976).

22. B. R. Morrison, I. A. Maxwell, R. G. Gilbert, and D. H. Napper, ACS Symp. Ser. (in press) (1992).

23. Y. Kawaguchi and Y. Doi, Macromolecules 25, 2324-2329 (1992).
24. E. Berger, B. A. Ramsay, J. A. Ramsay, and C. Chaverie, Biotechnol. Tech. 3, 227-232 (1989).

25. C. Pedrós-Alió, J. Mas, and R. Guerrero, Arch. Microbiol. 143, 178-184 (1985).

26. S. Tal and Y. Okon, J. Microbiol. 31, 608-612 (1985).

27. Y. Doi, A. Segawa, Y. Kawaguchi, and M. Kunioka, FEMS Microbiol. Lett. 67, 165-170 (1990).

28. J. Kurja, G. J. M. de Koning, H. F. Zirkzee, and I. A. Maxwell (in preparation).

29. G. J. M. de Koning and P. J. Lemstra, Polymer 33, 3292-3294 (1992). 